
www.globaljournalseries.com; globaljournalseries@gmail.com

\title{
SCALING UP SELF- REGULATORY ABILITY IN CHILDHOOD EDUCATION AS CORRELATE OF CREATIVE MINDSET
}

\author{
SUNDAY, MARIA OFIE, OBOGO, GODWIN OBOGO AND ADIE, ROSE UNWANUNG
}

(Received 18, June 2021 Revision Accepted 11, August 2021)

\begin{abstract}
The study is on the need to scale up self - regulatory abilities in learners towards more sustainable national development in Nigeria. This study was instigated by the poor nature of children that need to create a background on purposeful activities in the learning environment. Three research questions raised which were translated into correspondent null hypotheses to guide the study. Some related literatures were reviewed accordingly. The study adopted a Survey research design with 218 samples selected through simple random sampling technique from primary school Pupils in Ogoja Education Zone of Cross River State. A four points likert scale questionnaire with eighteen items was adapted and validated and used for data collection. The reliability estimate was established for the instrument using the Cronbach alpha reliability method, the values were between 0.76 and 0.81 . Pearson product moment correlation method of analysis was employed to analyze the data. All hypotheses were tested at 0.05 level of significance. The result of the analysis revealed that all hypotheses were significant. Based on the findings, the researcher concluded that there was a relationship between self-regulatory learning ability and pupils' creative mindset. The use of SRL strategy by pupils significantly correlates with pupils' creative mindset. It was recommended among others that schools should organize sensitive educational programmes to develop children's creative mindset. Parents, teachers and caregivers should encourage the values of managing emotions, behaviour and learning in children.
\end{abstract}

KEYWORDS: Self-regulatory ability, Early childhood education, creative mindset

\section{INTRODUCTION}

People reckon that 21 st Century is the Century of knowledge. In this era of fierce competition, people with knowledge would survive and prosper. Researchers have been advocating a shift from teacher centred education to learner centred education. The researches done so far have proved that the level of achievement depends on students' ability to think independently and their level of professional achievement depends on their skill of putting into practice their learning.
Early child education is of immense value to any given society. By childhood education in this study, one is referring to the education which children receive from 6 to 12 years of age. It covers the period from the first years of childhood to the primary school. This period is the time when mental and physical development is extremely rapid and where many building blocks related to an individual's future life are formed and shaped. Therefore, the period is an important and a sensitive process. Early childhood period is a critical period for children to acquire abilities and one of the most important abilities that

SUNDAY, MARIA OFIE, Department of Educational Foundations Faculty of Education University of Calabar, Calabar Nigeria.

OBOGO, GODWIN OBOGO, Department of Educational Foundations Faculty of Education University of Calabar, Calabar Nigeria.

ADIE, ROSE UNWANUNG, Department of Educational Foundations Faculty of Education University of Calabar, Calabar Nigeria.

(C) 2021 Bachudo Science Co. Ltd. This work is Licensed Under Creative Commons Attribution 4.0 international license. 
should be promoted during this period is selfregulation. According to the psychosocial theory propounded by Erickson, (1968) during this period, children's entry into school brings with it a huge expansion in the child's social world. Teachers and peers take on increasing importance for the child, while the influence of parents decreases. Children now want to make things. Success brings with it a sense of industry, a good feeling about oneself and one's abilities. Failure creates a negative self-image, a sense of inadequacy that hinders future learning.

From early childhood period, a child is adequate for the development of self-regulation. With the help of the school environment, a child will become more capable to regulate his/her behaviours and emotions. A child who recognizes $\mathrm{him} /$ herself will also exhibit another form of selfregulatory development through expressing $\mathrm{him} /$ herself to others (Bronson, 2000). Also a child who starts pre-school education will take the first step towards regulating his/her own learning experience. Children's self-regulatory abilities during this period will also contribute to their learning of metacognitive abilities (Anderson, 2003). Early childhood period is particularly critical for the development of self-regulation, although it has developed rapidly from the first moments of a child. The development of selfregulation during this period occurs through children's encountering academic processes, encountering problem-solving situations, exchanging ideas with their peers, and asking for help from their teachers or parents (İsrael, 2007). All these show how important early childhood period is in the development of children's selfregulation.

Creativity is the tool to drive economic viability in the 21st Century. This is because the quality of human ideas, concepts and values determines the prosperity of individuals, groups and organization. Creativity is the most fundamental of all human resources, competencies and skills. It enables human beings to get the most out of experience and resources. Creativity is the way of dynamic change, leap of progress, and surprise. It propels organizations, catapults careers and generates potent growth. Without creativity man is not able to make full use of information and resources available but locked up in old habits, structures, patterns, concepts and perceptions (Akinboye, 2001). Creative generative, constructive and design thinking are therefore the driving forces of human development. If one asks a hundred people to give the meaning of creativity, they are likely to come up with a hundred different definitions. This is because creativity is an amazingly complex behaviour that is multi factorially determined. (Zimmerman, 2008).

Creativity, divergent thinking and innovation are becoming more important components in today's school curricular and have become valued skills that have found their way into many corporate cultures and job environments. In the learning situation, creativity involves the ability to evolve original and uncommon applicable methods to problem solving. Therefore, it is important that students' creativity is identified and fostered in classroom setting (Hamzal \& Kimberly, 2006). Creativity is an important factor on the child's ability to learn and adjust, the child needs creativity to be effective. Creativity level of individual is not only seen from the talent and the results of creative expression, but also from their motivation to express their creativity (Abbot, 2010).

Self-regulation is an ongoing internal activity in which people are all participating in this time as to enable control and direct his or her feelings, thoughts and actions. If an individual is good at self-regulating, the person will be able to sustain a good feeling on optimal state of attention; such a person can organize his or her thinking and coordinate one's actions to accomplish desired goals; manage stress, navigate emotions and control impulses. Self-regulated learning mainly consists of three domains, that is meta-cognition, emotional and behaviour.

Emotional self-regulation is important for helping children manage how they express emotions. For example, the problem students' experience in managing their frustration may make it dificult for them to concentrate on school-related activity, it may be useful to teach them how to walk away and cool down rather than to have an emotional outburst. The emotional frontier is truly the important frontier to conquer in human understanding. Emotions are the "spice of life". They provide colour, texture, meaning and creativity to every experience. The more aware, adaptable and comfortable one is with emotions, the more creative, innovative, meaningful and enjoyable life will be. Isen (1993) showed that positive emotions produce more creative and variable actions. Fredrickson, (2001) has argued that the broadened mindsets that accompany positive emotions, in turn, carry indirect and longterm adaptive benefits because broadening builds enduring personal resources. Through experiences of positive emotions, people are more creative, innovative, entrepreneurial, 
knowledgeable, resilient, socially integrated and healthy individuals. Behavioural self-regulation helps children demonstrate control over their actions. It helps students learn to resist the desire to shout out the answer to a problem when it is someone else's turn to speak. Cognitive selfregulation helps children follow rules and plan out the appropriate response (such as listening during story time). Children's ability to organize their learning experiences independently and to have self-regulatory abilities is an important step towards gaining higher-level cognitive abilities (Anderson, 2003). It is also obvious that cognitive abilities regarding school readiness are related to metacognitive self-regulation.

Consequently, this writing seeks to find out the relationship between children's self - regulatory ability and creative mindset and also provide answers to the following questions such as

1. What will be the contribution of emotional self-regulatory ability for creative mindset?

2. What will be the contribution of Meta cognitive self-regulatory ability for creative mindset?

3. How does behavioural self-regulatory ability relate to children's creative mindset?

Finding answers to these questions among other things will presently occupy researcher.

\section{DEVELOPMENT OF SELF-REGULATION IN CHILDREN}

The development of self-regulation occurs in different ways based on children's ages. For example; changes in physical self-regulation (sleep regulation and wake time) and emotional regulation (self-calming) occur during infancy (Ekinci-Vural, 2012). In this period, family, peers and social environments of a child affect his/her development of self-regulation (Lin, Lai \& Chang, 2016). The social-cognitive approach by Albert Bandura indicates that self-regulation is not a product of children's own discoveries based on their experiences, but rather a culturally transferred method to regulate and control learning in an optimum manner. This view is based on the assumption that the relationship between a child and the model for his/her socialization is important. Development of selfregulation is unlikely for pupils when there are no role models who know self-regulated learning strategies and transfers information about the effective use of these strategies (Zimmerman, 1995).

\section{REVIEW OF LITERATURES}

In the literature on self-regulation, people are viewed as goal-oriented systems that take actions in accordance with their goals and adjust their actions by means of feedback control. Successful self-regulation enables people to suppress short-term attractions for long-term goals, to resist the pleasure of instant fulfillment for delayed gratification, and to endure the frustration that can be accompanied with persisting during hard work or in the face of challenges (Bauer \& Baumeister, 2011).

Hoffman and Rus (2011) carried out a study to examine the relationship among pretend play, creativity, emotional self-regulation and executive functioning in children. Pretend play processes were assessed using the affect in play scale(APS), which measures children's cognitive and affective processes, such as organization of a plot or use of emotions. Sixty- one female participants in kindergarten through grades were assessed using APS to measure pretend play ability, a divergent thinking task (the Alternate Uses Test) a storytelling task assess creativity, a measure of executive functioning (the Wisconsin card Sorting Task, Short form, WCST scale and parent report on the Emotion Regulation Checklist (ERC). Using correlational analysis, pretend play significantly related to creativity as measure by divergent thinking and storytelling related to emotional regulation. Affect expression in play was significantly related to affect expression in storytelling suggestion crosssituational stability.

According to research by Jalaou (2015), there was significant relationship between selfregulation learning strategies and student's creativity. This research was conducted based on previous literature and research that said selfregulation is one of the most effective task motivation components to affect creativity (Pinterich \& Shank, 2002, in Jalaou 2015). Moreover, Zimpetakis (2010) conducted a research which revealed that a person who has high self-perceived creativity has a good time management skill (i.e. daily planning, long-range planning) as their self-regulation strategy. Selfregulated learning is a conscious planning, monitoring, evaluation and ultimately control of one's learning in order to maximize it. It is an ordered process that experts and seasoned learners like as practiced automatically. That means being mindful, intentional, reflective, introspective, self-aware, self-controlled and selfdisciplined about learning and its tools to becoming self-directed. Self-regulation is a 
cyclical process. Students who are motivated to reach a certain goal will engage in self-regulatory activities they feel will help them achieve that goal. The self-regulation promotes learning, which leads to a perception of greater competence, which sustains motivation toward the goal and future goals. It is not only an essential part of healthy emotional development; it is also vital for academic success.

According to Bold, (2005), children need cognitive, social and motivational abilities to be successful in school. These abilities include understanding others' emotions, understanding instructions and focusing attention, controlling their own emotions and behaviors, organizing social relations with peers, and collaborating. Attentional regulatory abilities such as focusing attention, following instructions; and social abilities such as collaborating, motivating oneself to succeed and expressing emotions ensure children's readiness to learn (Boyd, 2005).

According to Bitar, (2010) children's creative mindset depends on the development of selfregulatory abilities during early childhood period. Children's abilities such as planning a task, controlling their impulses, following instructions, and focusing are abilities that get them to succeed in the academic field. It is also known that children who are good at self-regulatory abilities during early childhood period develop mathematics and literacy abilities in the future too. (Bronson, 2000).

Moreover, previous research had suggested the association of creative potential to some personality traits, such as high impulsivity and low conscientiousness, both of which have been reported as related to self- regulation (Baumeister, 2006). Research equally showed that self-regulation has been associated with aspect of creativity. Children who exhibit more imagination and affect in self-regulation tend to be better divergent thinkers and able to selfregulate. (Andreasen, 2002). Children begin to learn self-regulation in their homes through modeling, encouragement, facilitation, rewarding of goal setting, good strategy use, and other processes (Martinez-Pous, 2002). This notion is recognized by some empirical evidence (Holmes, 2004). Studies show that the forms of creativity in children depends upon individual interest and ability, opportunities to do what they want to do and activities that give the greatest satisfaction. Andreasen, (2006) explained that creative cognition results from a self-organizing system. This self-organizing system is part of the selfregulation component (Zimerman, 2002).
Many studies like the University of Virginia's Claire Cameroon Ponitz and Oregon State University's Megan McClelland (2010), showed that children with high levels of self-regulation do better on tests when compared to children with low levels of self-regulation. Baumann (2005) sees the inability of self-regulation as the root cause of the economic achievement gap. According to Baumann, students who are goal oriented and productive, also integrate and apply various learning strategies and design their behaviour to optimize their academic performance. The learners are motivated, selfdirecting, self-monitoring and self-evaluating (Zimmerman\& Schunk 2004). Such children are also more flexible and adapt to changes easily. Researches have shown that self- regulated learners set clear and realistic goals, use strategies, self- monitor and evaluate their progress, as well as complete tasks on time, report high level of motivation and exhibit skill acquisition (Zimmerman, 2000).

Kitsanta (2000) pointed out that self- regulated learner is a strategic planner, has the ability to select strategies that will enable him to accomplish these goals. Kitsanta went further to say learners who are highly capable of self regulation can evaluate their strategies more often, experience greater self-satisfaction and make better adaptations than poorly selfregulated individual (Kitsanta, 2000). Schneider and pressley (2003) had shown that competent self -regulated learners have the knowledge and strategies needed to learn and remember information, and the ability to apply these skills to specific learning tasks. Koriat and Bjork (2006), stated that learners seem to rely on their metacognitve feeling in regulating their behaviour and, to the extent that these feelings are accurate, memory performance is improved (Koriat\& Bjork, 2006).

Andreasen and Press (2006) explained that creative cognitive results from a self-organising system. This self-organizing system is part of self- regulation components. Ivcevic and Mayer (2007) found that the scholar creative type is high on self-regulation components such as risk taking, and are able to generate multiple ideas when presented with a problem. Research equally showed that effective self-regulation not only underlies psychological well-being (Kaschel \& Kuhl, 2005), but also indicates healthpromoting behaviours, employee socialization and high job performance (Porath \& Bateman, 2006). Individuals who are self-regulated formulate their standards and keep track of their 
progress toward these standards. This view entails an active vision on people and suggests that people can regulate their own behaviour in order to enhance creative performance. Most researches on creative performance, in contrast, does not focus on what people can do to optimize their own creative performance, but on external influences (Byrne \& Shipman, 2010). However, as the path to high creative performance is a challenging one with many potential obstacles, a self-regulatory view is valuable and should be taken into account by research on creative performance.

Azeedo (2004), studied undergraduate students who were learning about the circulatory system using a hypermedia encyclopedia. The materials available to them included texts, diagrams, photographs, video clips and animated examples of how the circulatory system works. There were three different learning conditions. One group of students was told just to learn all they could about the circulatory system. A secondary group got the same instructions, but, in addition, they had a list of ten sub-goals to guide their learning. The third group had the list of sub-goals plus a self-regulation "coach", who helped them plan their learning, monitors their understanding, try different strategies and handle problems when they arose. Students in all three conditions were asked to "junk out loud" as they used the hypermedia materials - describing what they were thinking as they went through the materials. Students who had the support of a self-regulation coach who focused on task analysis, goal setting, using strategies and monitoring progress developed more complete and complex mental models of the circulatory system

\section{STATEMENT OF HYPOTHESES}

The following null hypotheses were used to test in the study:

1 There is no significant relationship between emotional self-regulatory ability and children's creative mindset.

2 There is no significant relationship between behavioural self-regulatory ability and children's creative mindset.

3 There is no significant relationship between meta-cognitive self-regulatory ability and children's creative mindset.

\section{METHODOLOGY}

The research design adopted for this study Expost facto research design under the survey research type. The population of the study consisted of 4360 all public primary four, five and six pupils in Northern Education Zone of Cross River State.

The sampling technique used for subject selection was the stratified random sampling technique. First the Northern Education zone was stratified into 5 local government areas. Ten schools were randomly selected from the study area, each of the schools. The proportionate sampling technique was used for each of the schools to arrive at the sample of 218 pupils for the study.

A research instrument titled: Self- regulation Scale and Creativity Questionnaire was used for data collection. The questionnaire had two sections consisting of a scale that measured respondents' demographic data, Section B was an eighteen items four point likert type scale that measured Self- regulatory ability and creative mindset. Respondents were required to indicate the level of agreement from SA, A, D and SD.

Self-Regulated Learning Strategy Instrument which consisted of 18 items was adapted from Hariseno (2012), which consisted of eighteen items, and used the 4points- Likert scales format ("Strongly Agree" to "Strongly Disagree"). The adapted instrument was subjected to a reliability test which gave alpha coefficient of 0.81 (reliable), (Kaplan and Saccuzzo, 2009). To increase the alpha coefficient, 7 bad items were deleted. Increasing score of alpha coefficient with 18 items was 0.77 (reliable) (Kaplan and Saccuzzo, 2009).

Out of 218 copies of questionnaires that were administered to primary five and six pupils, 200 copies were successfully completed and retrieved from the sampled schools. Pearson Product Moment Correlation Coefficient was used to test the hypotheses of the study making the actual sample used to be 200 .

\section{RESULTS \\ Hypothesis one}

There is no significant relationship between emotional self-regulation and pupils' creative mindset. The independent variable in this hypothesis is emotional self-regulation while the dependent variable is pupils' creative mindset. Pearson product moment correlation coefficient was used to test this hypothesis at 0.05 level of significance and the result is presented in Table 1. 
TABLE 1:

Pearson Product Moment Correlation of emotional self-regulation and pupils' creative mindset

\begin{tabular}{llllll}
\hline Variable & $\mathrm{N}$ & Mean & SD & r-value & Sig. \\
\hline Emotional self-regulation & 200 & 6.63 & 1.22 & & \\
& & & & $0.811^{* *}$ & .000 \\
Pupils' creative mindset & 200 & 15.00 & 2.55 & & \\
\hline
\end{tabular}

*significant at 0.05 level; $\mathrm{df}=198$; critical $\mathrm{r}$ value $=0.098$

The result in Table 1 revealed that the calculated $r$ - value of $0.811^{*}$ is greater than the critical $r$-value of 0.098 at 0.05 level of significance with 198 degrees of freedom. By this result, the null hypothesis which states that, there is no significant relationship between emotional selfregulation and pupils' creative mindset is rejected while the alternate hypothesis was accepted. The magnitude of effect is high, this means that emotional self-regulation influence pupils' creative mindset.

\section{Hypothesis two}

There is no significant relationship between behavioural self-regulation and pupils' creative mindset. The independent variable in this hypothesis is behavioural self-regulation while the dependent variable is pupils' creative mindset. Pearson product moment correlation coefficient was used to test this hypothesis at 0.05 level of significance and the result is presented in Table 2.

TABLE 2:

Pearson product moment correlation of behavioural self-regulation and pupils' creative mindset

\begin{tabular}{llllll}
\hline Variable & $\mathrm{N}$ & Mean & SD & r-value & Sig. \\
\hline Behavioural self-regulation & 200 & 7.83 & 2.31 & \multirow{2}{*}{$0.689^{*}$} & .000 \\
Pupils' creative mindset & 200 & 15.00 & 2.55 & & \\
\hline
\end{tabular}

${ }^{*}$ significant at 0.05 level; $\mathrm{df}=198$; critical $\mathrm{r}$ value $=0.098$

The result in Table 2 revealed that the calculated $r$ - value of $0.689^{*}$ is greater than the critical $r$ value of 0.098 at 0.05 level of significance with 198 degrees of freedom. By this result, the null hypothesis which states that, there is no significant relationship between behavioural selfregulation and pupils' creative mindset is rejected while the alternate hypothesis was accepted. The magnitude of effect is high, this means that behavioural self-regulation influence pupils' creative mindset.

\section{Hypothesis three}

There is no significant relationship between cognitive self-regulation and pupils' creative mindset. The independent variable in this hypothesis is cognitive self-regulation while the dependent variable is pupils' creative mindset. Pearson product moment correlation coefficient was used to test this hypothesis at 0.05 level of significance and the result is presented in Table 3

\section{TABLE 3:}

Pearson Product Moment Correlation of cognitive self-regulation and pupils' creative mindset

\begin{tabular}{llllll}
\hline Variable & $\mathrm{N}$ & Mean & SD & r-value & Sig. \\
\hline Cognitive self-regulation & 200 & 9.74 & 3.15 & \multirow{2}{*}{$0.632^{*}$} & .000 \\
Pupils' creative mindset & 200 & 15.00 & 2.55 & & \\
\hline
\end{tabular}

${ }^{*}$ significant at 0.05 level; $d f=198 ;$ critical $r$ value $=0.098$ 
The result in Table 3 revealed that the calculated $r$ - value of $0.632^{*}$ is greater than the critical $r$ value of 0.098 at 0.05 level of significance with 198 degrees of freedom. By this result, the null hypothesis which states that, there is no significant relationship between cognitive selfregulation and pupils' creative mindset is rejected while the alternate hypothesis was accepted. The magnitude of effect is high, this means that cognitive self-regulation influence pupils' creative mindset.

\section{DISCUSSION OF FINDINGS}

The result agrees with the findings of Isen (1987, 1993) which showed that positive emotions produce more creative and variable actions. Also Fredrickson, (2001) had argued that the broadened mindsets that accompany positive emotions, in turn, carry indirect and long-term adaptive benefits because broadening builds enduring personal resources. Through experiences of positive emotions, people are more creative, innovative, entrepreneurial, knowledgeable, resilient, socially integrated and healthy individuals.

This result supports what Baumann (2005), and Zimmerman \& Schunk, (2004) reported. According to them, students who are goal oriented and productive, also integrate and apply various learning strategies and design their behaviour to optimize their academic performance. Such learners are motivated, selfdirecting, self-monitoring and self-evaluating (Zimmerman\& schunk, 2004). They are more flexible and adapt to changes easily. This finding equally agrees with Martinez-Pous (2002) who reported that children begin to learn selfregulation in their homes through modeling, encouragement, facilitation, rewarding of goal setting, good strategy use, and other processes. This notion is recognized by some empirical evidence (Holmes, 2004).

Studies show that the forms of creativity depend upon individual interest and ability, opportunities to do what they want to do and activities that give the greatest satisfaction. Moreover, this result agrees with what Andreasen and Press (2006) reported that cognitive self-regulatory is resulting from a self-organizing system. This selforganizing system is part of self- regulation components. Also, Ivcevic and Mayer, (2007) equally found that the scholar creative type is high on self-regulation components such as risk taking, and are able to generate multiple ideas when presented with a problem.

\section{CONCLUSION}

The social world requires ones to control his/her behaviours, emotions, and thinking. Control over oneself is a skill that helps an individual to navigate his or her surroundings fluidly, resolve conflict, solve problem, think independently, participate and get along with others. So, in order for an individual to be successful in all things in life, self-regulation skills are a vital tool. However, at the beginning of the $21^{\text {st }}$ century, it has been recognized that in order to make creative pursuits workable, individual use self-regulatory findings to monitor, evaluate and strategically act on their behaviour. Sustaining creative efforts on a regular basis is a great challenge for even the most creative people. From time to time, we all get stuck and feel empty for want of ideas. The work of behavioural psychologists suggests that designing work strategies may help sustain productivity.

\section{RECOMMENDATIONS}

(i) Based on the main result of this study, it is recommended that students should be helped to improve on their self- regulated learning because the higher degree of students' active participation in terms of metacognition, motivation, and behaviour, the better an individual's state-like belief in his or her own ability to perform the specific tasks required to produce novel, original, or appropriate solutions (the better their creative mindset)..

(ii) Schools should also organize sensitive educational programs to develop children creative mindset

(iii) Parents, teachers and caregivers should encourage the values of managing one's emotions, behaviour and meta-cognitive learning in children

(iv) The role of parents and teachers in early childhood period, where great changes and developments in self-regulation occur, is quite effective. In this regard, it is important to provide the necessary support to improve children's selfregulatory abilities starting from early childhood period and to get parents and teachers to be aware of the importance of self-regulation.

(v) Children need adequate monitoring and guidance by their parents and teachers while they also need psychological independence to be able to regulate themselves and gain competences. This depends on the appropriate life experiences provided to a child to control his/her emotions, thoughts and behaviour as well as on the attitudes and behaviours of parents and teachers towards the child. In this regard, a self- 
regulation training program including situations that promote the development of self-regulation can be prepared and conducted to parents and teachers.

\section{REFERENCES}

Abbot, D. H., 2010, May. Constructing a Creative Self Efficacy Inventory: A mixed methods inquiry. Disertation.

Andreasen, N. C. and Press, D., 2006. A review of the creating brain: The neuroscience of genius. Psychology of Aesthetics Creativity and Arts, 8, 51-67.

Beeftink, F., Van Eerde, W., Rutte, C. G., and Bertrand, J. W. M., 2012. Being successful in a creative profession: The role of innovative cognitive style, selfregulation, and self-efficacy. Journal of Business and Psychology, 27(1), 71-81.

Bolland, A. J., 2002. Becoming a self-regulated learner: A overview. Theory into Practice, 41, 64-72.

Hariseno, H., 2012. The Correlations Between Self-Regulated Learning, Holland's Personality Type, and Academic Achievement in Music College Students. Thesis. Depok: Faculty of Psychology, University of Indonesia.

Hamza, M. M., Kimberly, G. G., 2006. Fostering problem solving and creative thinking in the classroom: Cultivating a creative kind. National Forum of Applied Educational Research Journal Electronic, 9(3).

Holmes, F. L., 2004. Investigate pathways: Patterns and stages in the careers of experimental scientists. New Helven: Yale University Press.

Ibrahim, N. L. N., and Utaberta, N., 2012. Learning in Architecture Design Studio. Procedia-Social and Behavioral Sciences, 60, 30-35.
Jalou, M., 2015. The relationship between goal orientation, self- regulation learning strategies and creativity in high school students of Tehran city. Journal UMP Social Sciences and Technology Management Vol, 3(2).

Kaplan, R. M. and Saccuzzo D. P., 2009. Psychology Testing: Principle, Application, and Issues (6th ed.). Belmont: Thomson Wadsworth. Kementerian Pariwisata dan Ekonomi Kreatif Indonesia., 2014. Siaran Pers: Rencana Pengembangan Ekonomi Kreatif 2015-2019.

Kumar, R., 2005. Research Methodology 2nd ed.. London: Sage Publication.

Perverly, Brobst, Graham and Show, 2003. College adults are not good at selfregulation. A study on the relationship of self-regulation, note taking and test taking. Journal of Educational Psychology, 95(2), 335-346.

Pintrich, P. R., and Zusho, A., 2002. The development of academic self-regulation: The role of cognition and motivational factors. In A. Wigfield and J. Eccles (eds.). Development of Achievement Motivation. San Dego, CA: Academic Press, 249-284.

Simonton, D. K., 1994. Greatness: Who makes history and why. New York: Guilfrod Press. Utami, M. N., 2009. Memperkenalkan Konstektual Proyek pada Pelaksanaan Studio Perancangan Arsitektur Tingkat Lanjut.

Wolff, K. A., 2009. The Architecture Studio: Its implications for instructional design education. Teachers College, Columbia University.

Zampetakis, L. A., Bouranta, N., and Moustakis, V. S., 2010. On the relationship between individual creativity and time management. Thinking Skills and Creativity, 5(1), 23-32. 
Zimmerman, B. J. and Schunk, D. H., 2004. Selfregulating intellectual processes and outcome: A social cognitive perspective. In D. Y. Dia and R. J. Sternberg (Eds.). Motivation, emotion and cognition: Integrative perspectives on intellectual functioning and development. Mahwah, NJ: Lawrence Erlbaum, 143-174.

Zimmerman, B. J., 2000. A henmenert of self regulation: A social cognitive perspective. In M. Bockaerts, P. R., Pintrich and M. Zeider (Eds). Handbook of Self Regulation. San Diego, CA: Academic Press, 13-39.

Zimmerman, B. J. and Schunk, D. H., 1988. Selfregulated learning from teaching to self- reflective practice. New York: Guilford Press, 213-216.

Zimmerman, B. J., 1989. A social cognitive view of self-regulated academic learning. Journal of educational psychology, 81(3), 329-342.

Zimmerman, B. J., 1990. Self-regulated learning and academic achievement: An overview. Educational psychologist, 25(1), 3-17.

Zimmerman, B. J., 2008. Investigating selfregulation and motivation: Historical background, methodological developments, and future prospects. American Educational Research Journal, 45(1), 